\title{
Web-Based Application to Support Physical Fitness Information of Elderly People
}

\author{
Aplikasi Berbasis Web untuk Menunjang Informasi Kebugaran Jasmani \\ Orang Lanjut Usia
}

\author{
Yudhy Dharmawan*, Suroto**, Priguna Septia Putra****
}

*Biostatistics \& Population Studies Department, Faculty of Public Health, Diponegoro University, Semarang, Indonesia, ** Occupational Health and Safety Department, Faculty of Public Health, Dipenogoro University, Semarang, Indonesia, **** Computer Laboratory, Faculty of Public Health, Diponegoro University, Semarang, Indonesia

\begin{abstract}
The number of elderly people is more increasing along with the rising of the life expectancy age. There are many efforts that should be carried out to prevent the elderly, one of which from the preventive aspect is by maintaining the physical fitness of the elderly. To monitor the fitness status of the elderly, it needs an application of the web technology-based physical fitness monitoring because has been no system that records elderly fitness data. This application was to record physical fitness data of the elderly to recommend the appropriate gym based on the health condition which can be accessed anywhere. This application was made with the PHP and MYQSL program language as the database processing equipped by the graphic to monitor the physical fitness. The results of the test showed that the application worked properly. As indicated by the functioning of the designed and developed menues. The system was able to record the individual data and the physical fitness of the elderly, also able to serve the information and the records of the fitness of the elderly people and the appropriate recommendation on fitness exercise.
\end{abstract}

Keywords: Elderly, information system, physical fitness, web-based application

\begin{abstract}
Abstrak
Penduduk lanjut usia (lansia) semakin banyak seiring meningkatnya usia harapan hidup. Banyak upaya yang harus dilakukan untuk mencegah kesakitan di lansia, salah satunya dari aspek preventif dengan menjaga kebugaran para lansia. Untuk memonitor status kebugaran lansia, maka diperlukan aplikasi pemantauan kebugaran jasmani berbasis teknologi web karena tidak ada sistem yang merekam data kebugaran para lansia. Aplikasi ini ditujukan untuk merekam data kebugaran jasmani para lansia untuk merekomendasikan gym yang sesuai berdasarkan kondisi kesehatan yang dapat diakses di mana saja. Aplikasi ini dibuat dengan bahasa pemrograman PHP dan MYSQL sebagai pengolahan basis data yang dilengkapi dengan grafik untuk memantau kebugaran jasmaninya. Hasil uji menunjukkan bahwa aplikasi mampu berfungsi dengan baik yang ditunjukkan dengan berfungsinya seluruh menu yang didesain dan dikembangkan. Sistem mampu merekam data individu serta kebugaran lansia. Sistem mampu menyajikan informasi dan riwayat kebugaran lansia serta rekomendasi latihan kebugaran yang sesuai.
\end{abstract}

Kata kunci: Lansia, sistem informasi, kebugaran jasmani, aplikasi berbasis web

How to Cite: Dharmawan Y, Suroto, Putra PS. Web-based application to support physical fitness information of elderly people. Kesmas: National Public Health Journal. 2018; 13(1): 23-29 (doi:10.21109/kesmas. v13i1.1448)
Correspondence: Yudhy Dharmawan, Faculty of Public Health, Diponegoro University, Prof. Soedarto SH Street, Tembalang Semarang, Phone: +62247460044, E-mail: yudhydharmawan@gmail.com

Received: February $21^{\text {th }} 2017$

Revised: January $25^{\text {th }} 2018$

Accepted: May 16 2018 


\section{Introduction}

In Indonesia, there is a rising life expectancy age from 68.6 in 2012 to 70.8 in 2015. The Indonesian Central Bureau of Statistics predicts the rising portion of elderly people, above the sixty years old, from $8.5 \%$ in 2015 to $10 \%$ in 2020 . The morbidity rate of elderly population in 2014 is at $25.05 \%$. The results of 2013 National Basic Health Research indicate that almost all the elderly people suffer from the illnesses which are the non-communicable diseases, such as hypertension, arthritis, stroke, lung diseases, chronic obstruct and diabetes mellitus (DM). The Health Minister tries to make the elderly have qualified health referring to the World Health Organization (WHO)'s concept of Active Aging, that is the aging process which is still healthy physically, socially, and mentally in order to be prosperous along their lives and still be participated in increasing the life quality as the society. ${ }^{1}$ To reach those efforts, the elderly are suggested to have the fitness activities by doing exercises such as gym for the elderly people to prevent and slow down the degeneration of body functioning. ${ }^{2}$ The continuing and the proportional exercises will help the deceleration of aging process and decrease the elderly's dependency on their children or their families. ${ }^{3}$ The elderly practicing Tai Chi regularly are proven to increase 16.01 $\mathrm{VO}_{2}$ Max. In general, Tai Chi Chuan training program is effective for improving the elderly's health and fitness. ${ }^{4}$ The fitness activities have been done by the elderly community, such as Healthy Heart Group. However, there has been no system that records their fitness data like the lung capacity $\left(\mathrm{VO}_{2} \mathrm{Max}\right)$, the pulse, and the blood pressure. By the records of the lung capacity $\left(\mathrm{VO}_{2} \mathrm{Max}\right)$, the pulse, and the blood pressure of the elderly, the elderly's fitness and health records will be documented. It will make the health services easier, such as the health centers called primary health care and integrated health care for the elderly people to monitor their fitness condition, and they can take the preventive action needed due to the decreased condition of the elderly's fitness.

To facilitate the records and the data analysts that produce the useful information for both the elderly and the health provider, it is important to make the information computerized technology to record the elderly's health and to minimize the fault in processing the data. The information system is also accessible anywhere by the media and the social tool generally. Therefore, it takes a web-based information system to facilitate data storage and to access information. By a web-based information system, it can record the elderly's fitness, so the physical condition of the elderly can be found out. Then an appropriate recommendation on physical activity can be given to the elderly, wherever the elderly or the health providers are. This makes the elderly easily know their fitness condition any time, regardless of the health work- er. Likewise for the health providers, it will facilitate them to access information related to the elderly's fitness conditions to determine appropriate health services.

Web-based elderly health information service system contributes to the elderly's health promotion. There was statistically significant difference in the knowledge, attitudes, and behaviors of the elderly before and after education via the homepage. ${ }^{5}$ The use of online health information was strongly connected to the "health knowledge, attitudes and practices'. ${ }^{6}$ Study by Lee, ${ }^{7}$ showed that the regular use of Health Improvement and Management System (HIMS), which instantly provides subjects biofeedback on their measured body weight, body mass index (BMI), body fat and blood pressure using a database that significantly the subjects' body weight, BMI, and blood pressure stores subjects-customized information has decreased. Subjects who used the system more frequently showed significant improvement in their body weight, BMI, and body fat. Web-based information system is low cost to raise men's awareness. ${ }^{8}$ By using webbased technology, the elderly's health and fitness can be recorded and accessed wherever more easily as long as the internet network connection is available. The elderly, healthcare providers, fitness trainers and the elderly's families can more easily monitor the elderly's fitness conditions as long as they have an account, so that the appropriately recommended physical exercise for the elderly fitness can be more easily implemented. Web-based technology is sufficient for the data recording and monitoring whose purpose is to produce the elderly's fitness status and the appropriate recommendations on physical exercise, without the need of the addition of mobile sensor technology.

This study was to make the elderly's fitness monitoring application that is able to provide the appropriate gym recommendation based on the health condition that is accessible anywhere by the internet.

\section{Method}

The study method was developmental research by using prototype system developmental method. This method is suitable for the system or customized software; it means the created software is based on demand and necessity.

There are several steps of the prototype system. The first step is planning. This step consists of collecting and analyzing the necessity. This stage is observed about the specification of the hardware necessity and the specification of the software necessity. The next step is designing the model using the use case diagram for behavior modeling of the information system that will be made. ${ }^{9}$ The use case diagram graphically illustrate the interaction between the system and external systems and the user. It describes who will use the system and in what ways the 
users expect to interact with the system. ${ }^{10}$ This step is also about designing the flowchart that is analytic system to explain the aspects of information system obviously, exactly, and logically. The flowchart used a group of standard symbol to explain the transaction process procedure in a system. ${ }^{11}$ Flowchart is to describe and do modeling about the process and data flow from the input to the output or how data must be stored or processed. It shows the input, outputs and data interaction for the event. ${ }^{10}$

The second step is the implementation which builds a prototype, by using some applications such as (a) PHP or XAMP, which is a free software or unpayable, so that the web is able to be dynamic in order to make website maintenance easier and efficient; MySQL which includes the open source database server that is a software of SQL database management system or DBMS that is multithread, multiuser; Web Server that is a software which manage and handle the program based on the browser demand and resend the browser. ${ }^{12-14}$ This step includes installing the software to the computer and implanting the fitness monitoring application. This section consists of two steps that are installing the software to the computer and implanting the fitness monitoring application.

The third step is doing an evaluation by using Black Box method. There are three test areas, testing the login function, data storage function and data reading function. If prototype is already perfect, then the start of product development with wider scale could begin. ${ }^{15}$ The sample of the study was the elderly group in Sampangan District, in Semarang City, Central Java Province in October 2016. This study applied purposive sampling technique by selecting the elderly who were willing to measure and know their fitness status. The number of samples was 12 people.

\section{Results}

At planning stage, identification of needs and system modeling is required. System modeling describes the flow of data to be processed into information. Model illustration uses a flowchart or block diagram, so that the flow of data and information, as well as interaction with the user are clearly illustrated.

This chapter describes the specification of the hardware necessity, the software necessity, use case diagram (Figure 1), and flowchart (Figure 2 and Figure 3) to plan the system which would be built. The specification of the hardware necessity in creating the fitness application was a computer with minimum specifications, which were dual core processor, 1GB RAM, and 50GB hard disk. The specification of the software necessity in creating the fitness application was a computer with minimum specifications, which were XAMPP as the simulator of web server and as the database, sublime as the editor of program code, and browser chrome as the compiler to exe- cute the application. Then in planning system design, this step was to plan describing and modeling the system by Use Case Diagram and Flowchart of the process. The application of use case diagram can be seen in Figure 1 . The Use Case Diagram describes that the user system consists of non-user, user, and administrator interacting with the menu of system.

Figure 1 shows that there are three users with the different authorities to access the menu of the fitness application. Flowchart is used to describe the logic of data flow from input to output information, and to describe the sequence of data processes in the system. The flowchart also delineates the logical sequence of work performed within the system known as events or transactions.

To design the application menu, it needed the flowchart designing for drawing the fitness application process, the first was to make a login menu flowchart (Figure 2). Figure 2 shows the process on the main menu to do the new user registration or fill the new fitness data from the result of jogging or Harvard test. Then the flowchart for the process of filling data on the menu of application list was made. In this menu, filling data included complete name, birth date, sex, address, and phone number.

Then the flowchart for process design to enter the ap-

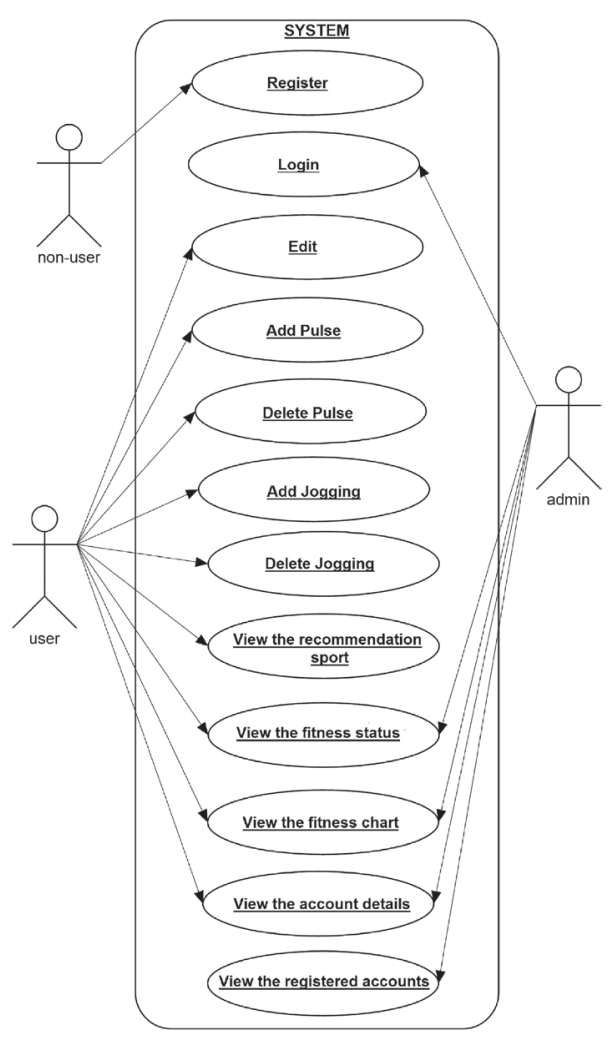

Figure 1. The Application of Use Case Diagram 


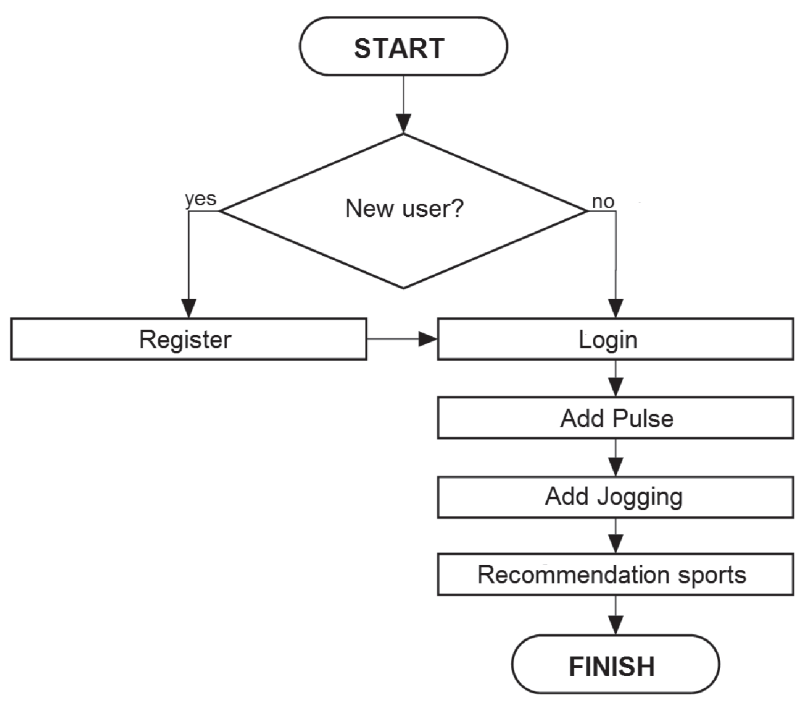

Figure 2. The Application of Main Flowchart

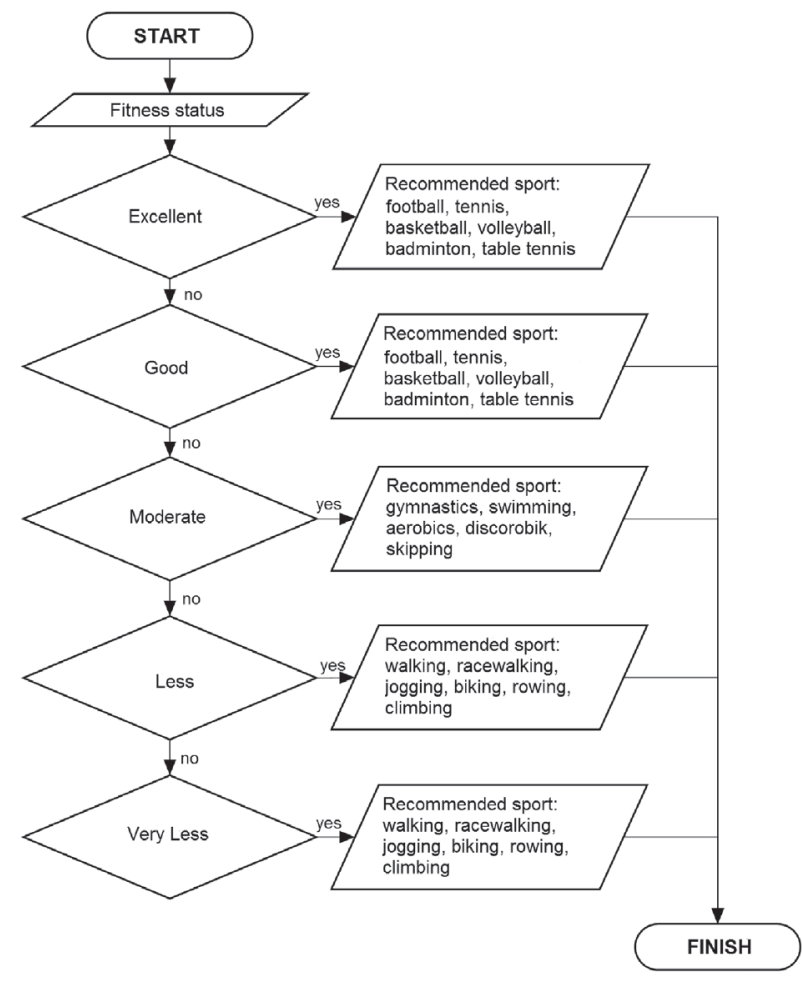

Figure 3. The Recommendation Flowchart

plication was made. It was designed to make the user who only had the account could access the information on their own fitness.

The next was the flowchart for menu to record the elderly's fitness data with jogging exercises to measure $\mathrm{VO}_{2}$ Max and Harvard Step Test to measure the pulse. Input data in this menu were pulse beat and the number of minutes and seconds. The designing process also illustrated the process of the input data result to show the condition of the fitness. The fitness record is very essential to be noted because it pushes the elderly people to get motivated for doing exercises which are approved effectively to boost the stability of the elderly people's body.

Figure 3 shows the process of giving recommendation on fitness exercises which are appropriate with the fitness condition, so that each user who enters the fitness data will get the fitness status and the appropriate fitness recommendation.

Implementation stage with Prototype approach is a continuation of modeling by making a system with the programming language and then apply it. This stage is continuing the model design, building and implementing it into information systems with minimal, usable system capabilities and features. The implementation is the result of the part of designing, also the step to make the results based on the designing step before. In term of installing the software to the computer, installing the software XAMPP was to stimulate the computer into web server. Then in the step of implanting the application of the fitness monitoring, the fitness monitoring application was installed in the computer. Then, it opened the browser program to operate the fitness monitoring application. The implementation is shown in the main menu interface slide show.

The display of the results of the fitness data analysis is shown in Figure 4, which shows the fitness status, the fitness records and the fitness exercise recommendation based on the last data.

For monitoring the development of the fitness status of each user, the display was made as in the Figure 5, which shows the line graphic of the fitness development.

The evaluation system used the testing of black box system namely the method of software which is functionality testing from the contrary application with the internal structure. Black box testing attempts to find errors in several categories, including functions that are wrong or missing, interface errors, errors in data structures or external database access, performance errors, and initialization and termination errors. Black box testing focuses on the functional specifications of the software.

The evaluation system was done by selected samples to use the application by entering data pulse after practice and jogging time was taken several times. The study observed the function of the application whether it went as expected. The result of the functional test is stated on the table below.

The test results indicate that the design and the system implementation have shown the good results by the all the developed system functioning. The aplication test result can see at Table 1 . 


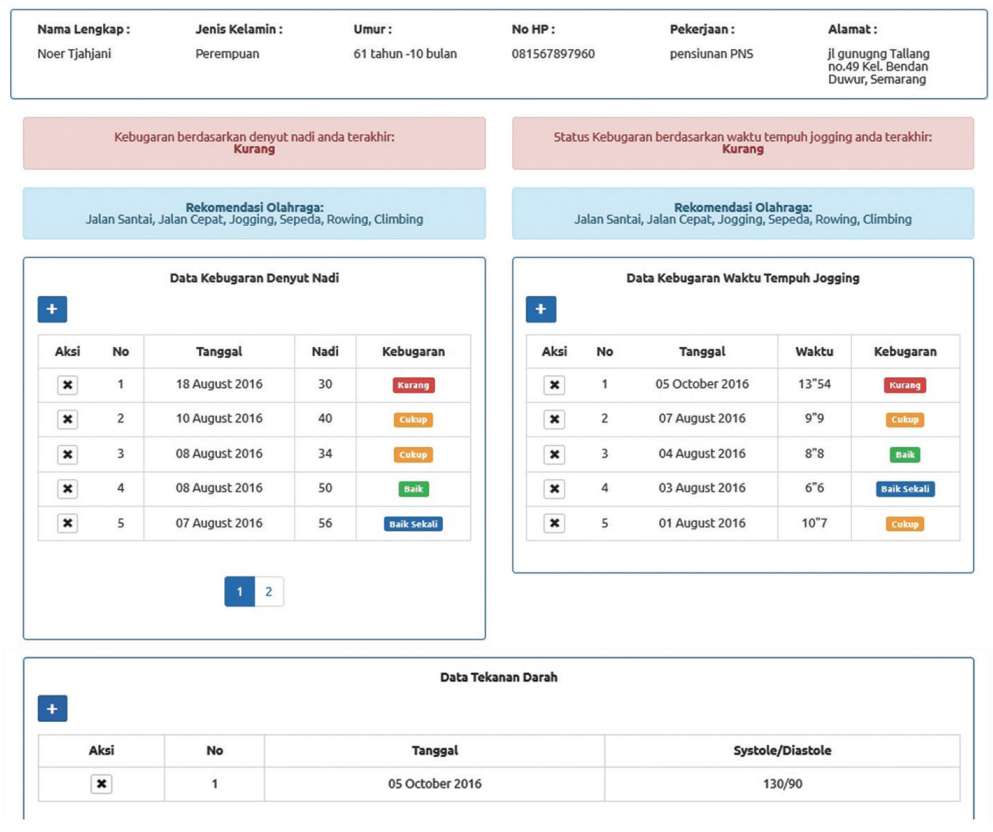

Figure 4. The Display of the Fitness Results

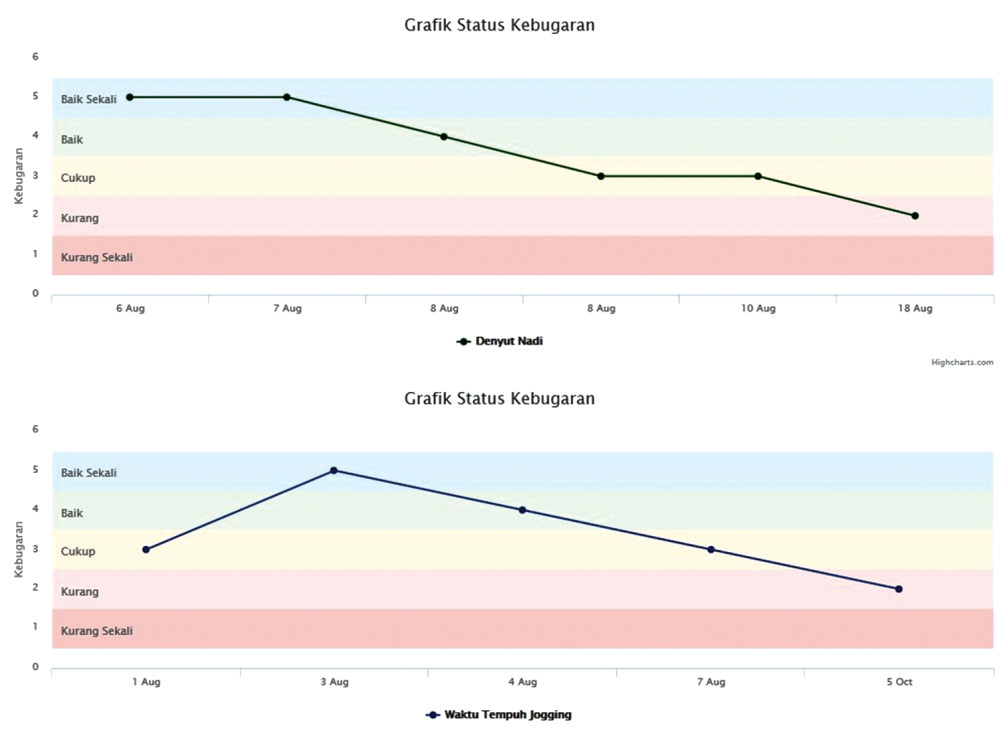

Figure 5. The Display of User Graphic

\section{Discussion}

The elderly, both male and female, aged between 6069 years old as their fitness should be maintained. The health condition of the elderly is not only the responsibility of the health services, but also all people. The sport activity will help the body fit and fresh because it practices the bone to be strong, push the heart work optimally, and help relieve the free radical which roams in the body; in other words, having the good fitness physically means the heart and blood circulation are good, so that the whole body can work as its functions in a long period. The appropriate sport for the elderly to reach the fitness is gym exercise combined by the strength exercises added by balancing and stretching movements. The right exercises are that the exercises which is appropriate with the condition of the elderly's fitness. However, the information of the appropriate condition of their fitness is very difficult. Moreover, the condition of the elderly is dynamic with the fitness condition which is not stagnant. Monitoring from time to time is needed. Many elderly 
Table 1. Application Function Test

\begin{tabular}{|c|c|c|}
\hline Test & The Expected Result & The Result \\
\hline The function of login & $\begin{array}{l}\text { The appropriate user data and password } \\
\text { can enter the application }\end{array}$ & Succeed \\
\hline The function of saving the user's data & $\begin{array}{l}\text { The user's data characteristics, such as name, } \\
\text { the birth date, address, etc which are able to be input } \\
\text { to the list menu, can be saved in the databasesystem }\end{array}$ & Succeed \\
\hline The function of saving the jogging data (Lung Capacities) & $\begin{array}{l}\text { The data of jogging period can be input in the } \\
\text { database system }\end{array}$ & Succeed \\
\hline The function of saving the pulse data & $\begin{array}{l}\text { The data of the pulse frequency can be input in the } \\
\text { database system }\end{array}$ & Succeed \\
\hline The function of reading the data of the user's fitness status & $\begin{array}{l}\text { The information of the fitness status appears and } \\
\text { match with the input data of jogging period and } \\
\text { the pulse frequency }\end{array}$ & Succeed \\
\hline The function of reading the recommendation data of the users fitness exercises & $\begin{array}{l}\text { The information of the exercises recommendation } \\
\text { appears and match with the input data of jogging } \\
\text { period and the pulse frequency }\end{array}$ & Succeed \\
\hline The function of reading the data records of the user's fitness & $\begin{array}{l}\text { The data information on the user's fitness based on } \\
\text { the time allotment appears in the forms of } \\
\text { tabulation and graph }\end{array}$ & Succeed \\
\hline
\end{tabular}

people did not know yet the measuring way of their fitness and the way of increasing their fitness. The elderly service still depends on health services by the health workers, which has not been optimal yet, especially in remote rural area. 16

These two constraints can be overcome by inputting the fitness data in the pulse beat and lung capacities which have been converted in the time unit of jogging in 1600 meter in this fitness monitoring application. Webbased health information system will make it easier for users to access health information. This is shown also with the result of geographic information system development of web-based public health services in Semarang City, which uses XAMPP as web server simulator, that the user respondents both domicile in Semarang City and outside Semarang City satisfy at $98 \% .{ }^{17}$ This proves that the web-based information system allows users to access information wherever they live in, including access to health information for the elderly. The development of this system uses prototype method. Prototype methods help a lot in testing the system quickly. This method is also used in testing the output results in the UKS information system in Purwakarta District. The prototype design is used for menu design and finding out the output of the UKS information system. The result of prototype shows that the system is able to produce the required information. ${ }^{18}$ Testing with the prototype method is also applied to test mobile health monitoring applications for the elderly, specifically to test the interface system. ${ }^{19}$

The test result by Black Box shows that the function of the fitness data records in the pulse beat and lung capacities was succeed. Likewise, the process of the fitness data that shows the fitness status as well as the recommendation of the appropriate fitness exercise with the fit- ness status were also succeed by this monitoring application system. Moreover, the record of the fitness data was also succeed which appeared in this system, so the development of the status of the elderly from the time to time can be known, as both the pulse condition and the lung capacities were succeed.

Likewise, the process of the fitness data showing the fitness status and the appropriate recommendation on fitness exercises with the fitness status were succeed as indicated by this monitoring application system. Moreover, the record of the fitness data was also succeed shown in this system, so the development of the elderly's fitness status from the time to time can be known, both for the pulse condition and lung capacities after doing Harvard Step test and jogging or health walk for 1600 meter. The fitness record data is very essential, especially from the people's health for preventive efforts and health promotion. These data can be used by the health organizer of the elderly people in health services facilities, like primary health care, integrated health care for the elderly, or the health gym group of the elderly nor to plan the fitness exercises or other health efforts related such as the management of health services facilities for the elderly. The elderly fitness data can also be used as a means of monitoring their own health, directly and in real time, so that it can be used for the management of their own health. Currently, many people with chronic diseases use tools for monitoring health itself. Wearable devices may provide insight into the progression and impact of illnesses and may provide insights with conditions in which activity levels or movement may be compromised, e.g., multiple sclerosis, depression, rheumatoid arthritis, pain, and chronic obstructive pulmonary disease. ${ }^{20}$

A health monitoring system for the elderly is impor- 
tant for themselves and their families. A health monitoring system for the elderly living alone can reduce anxiety for both the elderly subjects living alone and with their family members. ${ }^{21}$ This system also provides the health data based on the society especially for the elderly. This case will support the effort of the creation of the community-based health data system in the future.

\section{Conclusion}

Based on the design and the implementation of the fitness monitoring application, it can be concluded that the application is able to monitor the condition of a person's fitness and give the appropriate recommendation on his/her fitness condition. The application is able to save the records of the one's physical fitness shown either in the forms of data or graphic, and the application run well by using the web server simulation. To maximize this application, it can be implemented by using web server with the big capacities in order to be accessed anywhere.

\section{Acknowledgment}

We would like to thank Directorate of Research and Community Engagement at Ministry of Research, Technology and Higher Education for the support and the fund for dedication to the community by the use of city park for the elderly's fitness, in which the application for the elderly's fitness is one of the interventions applied. We also thank the Semarang City Government and the elderly groups in Gajahmungkur and Sampangan Districts which have supported the fitness of the elderly by using the application for the elderly's physical fitness.

\section{References}

1. Pusat Data dan Informasi, Kementrian Kesehatan Republik Indonesia. Situasi lanjut usia di Indonesia. Jakarta: Kementrian Kesehatan Republik Indonesia; 2016.

2. Darmojo RB, Martono HH. Buku ajar geriatri. Jakarta: Balai Penerbit Fakultas Kedokteran Universitas Indonesia; 2004.

3. Afriwardi. Program latihan bagi kelompok lansia. Jurnal Kesehatan Masyarakat. 2008; 3(1): 35-37.

4. Lan C, Lai J-s, Chen S-Y, Wong M-K. 12-month Tai Chi training in the elderly: its effect on health fitness. Medicine and Science in Sports and Exercise. 1998; 30: 345-51.

5. Park H, Kim HJ, Song MS, Song TM, Chung YC. Development of a web-based health information service system for health promotion in the elderly. Journal of Korean Society of Medical Informatics. 2002; 8: 37-45.

6. Jang H, An JY. Social network analysis of elders' health literacy and their use of online health information. Healthcare Informatics Research. 2014. 20: 216-25.

7. Lee HJ, Kang KJ, Park SH, Ju SJ, Jin MH, Park BN. Effect of integrated personalized health care system on middle-aged and elderly women's health. Healthcare Informatics Research. 2012; 18: 199-207.

8. Gupta V. Hincapie AL, Frausto S, Bhutada NS. Impact of a web-based intervention on the awareness of medication adherence. Research in Social and Administrative Pharmacy. 2016; 12 (6): 926-36.

9. Nogroho B. Aplikasi pemrograman web dinamis dengan PHP dan MySQL. Yogyakarta: Gaya Media; 2008.

10. Bentley LD, Dittman KC, Whitten JL. Systems analysis and design methods. Irwin/McGraw Hill. 2001.

11. Shalahuddin M, Rosa AS. Analisis dan desain sistem informasi. Bandung: Politeknik Telkom. 2008.

12. Perangin angin, Kasiman. Aplikasi web dengan PHP dan MySQL. Yogyakarta: Andi Offset, 2006.

13. Krismiaji. Sistem informasi akuntansi edisi ketiga. Yogyakarta: Akademi Manajemen Perusahaan Yayasan Keluarga Pahlawan Negara; 2012.

14. Supardi Y. Web my profile dengan joomla. Jakarta: PT. Elex Media Komputindo; 2010.

15. Hermandra AD, Anofrizen. Pengembangan sistem informasi kerja praktek. Jurnal Rekayasa dan Manajemen Sistem Informasi. 2010; 2 (1): 114.

16. Pranomo LA, Fanumbi C. Permasalahan lanjut usia di daerah perdesaan terpencil. Kesmas: Jurnal Kesehatan Masyarakt Nasional (National Public Health Journal). 2012 ; 6(5): 201-11.

17. Putri GAS, Sudarsono B, Wijaya AP. Rancang bangun sistem informasi geografis pelayanan kesehatan masyarakat berbasis web (Studi Kasus: Kota Semarang). Jurnal Geodesi Universitas Diponegoro. 2014 ; 3(1) : 275-88

18. Johari. Pengembangan dan aplikasi sistem informasi usaha kesehatan sekolah (UKS) di Kabupaten Purwakarta. Kesmas: Jurnal Kesehatan Masyarakt Nasional (National Public Health Journal). 2008; 2(5) : 22633

19. Lorenz A, Oppermann R. Mobile health monitoring for the elderly: Designing for diversity. Pervasive and Mobile Computing. 2009; 5: 47895

20. Chiauzzi E, Rodarte C, Mahapatra PD. Patient-centered activity monitoring in the self-management of chronic health conditions. BMC Medicine. 2015; 13: 77.

21. Ohta S, Nakamoto H, Shinagawa Y, Tanikawa T. A health monitoring system for elderly people living alone. Journal Telemed and Telecare. 2002; 8(3): 151-6. 